Teka Kom. Politol. Stos. Międzynar. - OL PAN, 2017, 12/2, 7-29

\title{
U.S. PRESIDENT OBAMA'S CHINA POLICY: A CRITICAL ASSESSMENT
}

\author{
Elizabeth Freund Larus \\ Waple Professor of Political Science and International Affairs \\ at the University of Mary Washington and President of E Larus Consulting \\ e-mail: elarus@umw.edu
}

\author{
Shirley Naa-kowaa Martey Hargis \\ Research Assistant at E Larus Consulting
}

\begin{abstract}
US China policy has shown remarkable consistency throughout the past quarter century despite the ideological differences of US presidents. US presidents who subscribe to the liberal school of international relations have commonly sought to engage adversaries, to bring about positively change in the adversary. Realists are more likely to try to limit an adversary's influence by containing its power. Since the early 1990s, US presidents have employed both containment and engagement. The most liberal US president in the past 25 years, Barack Obama initially pursued engagement policy with China. Sensing China's challenge to US dominance of the Asia-Pacific, President Obama gradually adopted elements of containment policy. This article assesses the Obama administration's China policy. Specifically, it asks if US President Barack Obama pursued a divergent China policy. It finds that the Obama Administration's rebalance to the Asia-Pacific policy is consistent with the US China policies of earlier administrations.
\end{abstract}

Key words: US China policy, Barack Obama, Asia-Pacific region

\section{INTRODUCTION}

US policy toward China since the normalization of diplomatic relations in 1979 can be described as one of "congagement" in which containment and engagement coincide. Congagement policy contains elements of both containment, which is an attempt to limit the power or influence of an adversary, and engagement, which is an attempt by two countries to positively interact or cooperate. Congagement is both a foreign policy, and a spectrum along which a foreign policy shifts in varying degrees of containment and engagement. US foreign policy in the post-Cold War 
era has at times emphasized containment, while at others put greater emphasis on engagement, moving back and forth along the spectrum according to Washington's threat assessment of the rival party. This article examines the Obama Administration's congagement of China. Specifically, it seeks to answer the question of whether US China policy under President Barack Obama was a departure from, or was consistent with, that of his predecessors. The article finds that, although Obama's China policy began on the engagement side of the continuum, a perceived security threat compelled him to integrate elements of containment policy. As a result, Obama's China policy was largely consistent with that of previous administrations.

Containment was a US policy to limit the spread of communism abroad. During the Cold War, US containment policy had two main strategies. The first, orchestrated by George Kennan, emphasized keeping Western Europe and Japan out of Russia's orbit by fostering democracy and building strong market economies there. This form of containment was manifested in the Marshall Plan (officially the European Recovery Program, ERP), in which the United States gave over $\$ 12$ billion in economic support to help rebuild Western European economies after the end of World War Two. Rebuilding Europe and Japan would prevent them from being seduced by communism and falling into the Soviet camp. The Korean War and a perceived buildup of the Soviet military caused the United States to modify its approach to containment. In the 1950s, Washington adopted NSC-68 recommendations that the United States counter the Soviet threat with its own build-up of conventional and nuclear forces, effectively militarizing US containment policy.

From 1949 to 1969, the US applied containment policy to China. The establishment of the People's Republic of China in 1949 caused anxiety in the United States. Believing it to be a protégé of the Soviet Union, Washington feared that China would destabilize the Asia-Pacific by trying to export Communist revolutions in the region. Beijing's support of the Korean War, the 1952 and 1962 Taiwan Strait crises, China's 1962 border war with India, and its 1964 detonation of an atomic bomb all reinforced Washington's view that China was a threat to regional security. The United States tried to contain China by isolating it. Specifically, Washington refrained from establishing diplomatic relations with Beijing and pressured regional allies to do the same; kept the PRC out of the United Nations keeping the ROC in the China seat; signed Mutual Defense Treaty with Taiwan and stationed troops there; sought defense alliances with China's littoral neighbors Japan, South Korea and the Philippines; cut off trade with China and orchestrated an international trade embargo; and prohibited American from visiting China.

China's split with the Soviet Union in the 1960s made some in Washington reassess the China threat. By 1969 both the United States and China saw the Soviet Union as the greater threat. Washington dropped the embargo with China in 1969, and in the 1970s played the "China card," against the Soviet Union. Playing the "China card" required US rapprochement with China. The Nixon Administration removed some restrictions on commerce and travel between the United States and China; ended the trade embargo in 1971; and President Nixon visited China in 1972. 
The US approach to China shifted yet again after the normalization of relations in 1979. In the 1980s, US policy began as one of wary alignment to one of engagement. Throughout the 1980s, Washington was generally optimistic about economic and limited political reform in China. Washington believed that engaging China would result in a more democratic regime willing to join the Western world order. The United States encouraged educational and cultural exchanges with China. Congress granted China Most Favored Nation (MFN) trade status, and even allowed the sale of US China dual-use technology to China.

In the 1980s, the three "Ts" of trade, Taiwan and Tibet had become an area of tension in US-China relations. The lure of the China market had generated a lot of enthusiasm among American business and investors in the 1980s. Economic reforms in China drew US manufactures to China, lured by an inexhaustible supply of cheap labor. US-China trade grew from $\$ 4.7$ million in 1971 to $\$ 4.8$ billion in 1980, a 1000 percent increase in 10 years. By 1984, the United States had become China's third largest trading partner, behind Japan and Hong Kong. China was the US' $14^{\text {th }}$ largest trading partner, however. By 1990, what had been a trade surplus of $\$ 1.7$ billion in 1981 had become a deficit of $\$ 10.4$ billion. The more American citizens saw of China's treatment of Tibet and human rights and religious abuses in Tibet the less they liked. The American media and Hollywood was vocal in their criticism of China's human rights record, and the US tied China's MFN status to the human rights issue. US support of Taiwan continued to be a thorn in Beijing's side. President Ronald Reagan signed a 1982 communique indicating that the United States would gradually reduce the quantity and quality of arms it sells to Taiwan. It perturbed Beijing that the United States was not committed to the letter of the communique.

The era of engagement ended abruptly on June 4,1989, when China's military opened fire on civilian demonstrators in Beijing and other Chinese cities. After this violence, US foreign policy toward China changed from cooperation to a combination of containment and engagement, called congagement. Under Congagement policy, the United States would continue to engage China with diplomacy and trade, while also using some containment strategies, such as strengthening ties with regional allies and friends to limit China's influence, and particularly, military might. ${ }^{1}$ Bilateral trade relations, the core of US engagement with China, were robust throughout the $1990 \mathrm{~s}$ and first decade of the $21^{\text {st }}$ century. In 1990, US-China trade was $\$ 20$ billion. By 2010, two-way was nearly $\$ 500$ billion. $^{2}$ Washington decoupled human rights issues from trade in 1994 and supported China's 2001 accession to the WTO.

\footnotetext{
1 A.L. Friedberg, A Contest for Supremacy: China, America and the Struggle for Mastery in Asia, New York 2011, p. 89.

2 US International Trade Commission, USITC Interactive Tariff and Trade DataWeb, 2016, available on-line: https://dataweb.usitc.gov (15.05.2017).
} 
Several crises occurred during these years, however, that negatively impacted US-China relations and gave ammunition to those who advocated a stronger containment policy toward China. These events were the 1995 and 1996 Taiwan Strait crises wherein the United States sent an aircraft carrier to the region in defense of Taiwan elections; the expansion of NATO and its involvement in the Balkan Wars; the 1999 US accidental bombing of China's embassy in Belgrade; and the 2001 collision of a US reconnaissance plane and a Chinese jet fighter which resulted in the death of the Chinese pilot. These events heightened Chinese concern over the liberal use of US military might. China accelerated modernization of its military.

As early as 1997 the Pentagon fingered China as a potential "global peer competitor." While the Pentagon claimed that it would continue to engage China, ${ }^{3}$ it was clear that the United States was increasingly wary of China. In 2001, the Pentagon implicitly identified China as a potential military competitor in the Asia-Pacific. ${ }^{4}$ Despite this assessment, the American and Chinese heads of state met three times in the twelve months between October 2001 and 2002. Both leaders pledged to ease tensions and move toward a constructive relationship of collaboration on issues ranging from tensions on the Korean peninsula, terrorism, WMD, climate change and global health issues. ${ }^{5}$ While seeing a constructive relationship with China, the United States at the same time deemed China as a rising threat to the security of the Asia-Pacific and adjusted its foreign policy. The United States would engage China in trade and the aforementioned critical issues, but would seek to contain China's growing military power.

In its 2002 National Security Strategy, the United States accused Beijing of pursuing advanced military capabilities that can threaten its neighbors, and warned that this strategy would only hamper China's pursuit of national greatness. ${ }^{6}$ Following the September 11, 2001 terrorist attacks, Washington focused its energies on the Middle East. Defense analysts at the Pentagon, however, argued that the rise of China was the longer-term security concern. The Bush White House was heavily realist in its foreign policy. The Bush Administration believed that, in an anarchical world order, it is sometimes necessary for the United States to act alone in its use of military force, rather than wait for the UN to invoke collective security. The Obama Administration came at foreign policy

3 US Department of Defense, Report of the Quadrennial Defense Review, Washington, D.C. 1997, p. 5, available on-line: http://history.defense.gov/Portals/70/Documents/quadrennial/ QDR1997.pdf?ver= 2014-06-25-110930-527(15.05.2017).

4 US Department of Defense, Quadrennial Defense Review Report US Department of Defense 2001, Washington, D.C. 2001, p. 4, available online: http://archive.defense.gov/pubs/ qdr2001.pdf (15.05.2017).

5 D. Wang, The United States and China: A History from the Eighteenth Century to the Present, Lanham, MD 2013, p. 290.

6 White House, The National Security Strategy of the United States of America, Washington, D.C. 2002, p. 27, available online: http://www.state.gov/documents/organization/63562.pdf (15.05.2017). 
from a liberal perspective in international relations. Liberalism emphasizes collective action carried out by multilateral and international organizations rather than by individual nation-states. As a result, the Obama Administration favored consensus-building and engagement in its foreign policy making.

The Obama Administration's policy toward China heavily favored engagement over containment. As its economic and military rise increased its importance and influence in the Asia-Pacific, China began to look like a threat to regional stability. Rather than treat China like a threat, and thereby try to isolate it, the Obama administration believed that it was more constructive to allow China a seat at the table rather than alienate it. According to this mentality, China would be more likely to go along with the prevailing world order if it had a say in the game, rather than sitting outside of it. This view was most pushed by Jeffrey A. Bader, NSC Asia director for the first Obama administration. This view was continued by Bader's successor, Evan Medeiros. Medeiros, who worked in the Obama White House from 2009 to 2015, was a key architect of Obama's rebalance policy, which called for greater diplomatic, economic and security efforts in the Asia-Pacific.

Between 2001 and announcement of the pivot in 2011, China had made great strides in modernizing its military and asserting its claims of sovereignty over disputed territories in the Asia-Pacific. Relatively unscathed by the 2008 global financial crisis that was wreaking havoc on the United States and the West, China became more nationalistic and assertive. It engaged in tussles in the East and South China Seas with Japan, Vietnam and the Philippines over maritime rights and territorial claims. Concern over what appeared to be an attempt to push the United States out of the region, the Obama Administration announced the pivot in late 2011 .

Despite diplomatic and economic engagement, the United States and China remain wary of each other. Beijing accuses Washington of fomenting tension in the region by encouraging its allies to instigate fights against China over disputed territory. It also accuses the US of portraying China as a bully in the region, making it difficult for Beijing to engage its neighbors.

\section{TRADE ISSUES}

The United State enjoys robust trade relations with China. China is the US's largest trade partner. Two-way trade in totaled nearly $\$ 660$ billion in 2015.? Despite these commercial relations, there are significant trade tensions between China and the United States. The most prominent US-China trade issues concern

7 Exports were $\$ 161.6$ billion; imports were $\$ 497.8$ billion. Office of the United States Trade Representative, The People's Republic of China, 2016, available online: https:/ustr.gov/ countries-regions/china-mongolia-taiwan/peoples-republic-china (31.10.2016). 
disputes over protection of US intellectual property rights (IPR), cyber security attacks against US firms, WTO infractions, and currency manipulation. ${ }^{8}$

Intellectual Property Rights. Intellectual property (IP) is a crucial source of US global competitiveness and economic growth. American firms claim that the lack of consistent and effective protection of IPR is one of the critical problems that they face doing business in China. In a 2013 study, the Commission on the Theft of American Intellectual Property ${ }^{9}$ estimated the annual loses to the US economy due to IP theft at around $\$ 300$ billion. China accounts for 50 to 80 percent of those losses..$^{10}$ According to a 2013 survey conducted by the American Chamber of Commerce in China (AmCham) 72 percent of those surveyed concluded that China's IPR enforcement was ineffective or entirely ineffective. ${ }^{11}$ A 2009 study by the United States International Trade Commission (USITC) found that IPR violations in China resulted in $\$ 48.2$ billion in losses from royalties, sales, and license fees. ${ }^{12}$ In 2011, the Business Software Alliance estimated that the commercial value of illegal software in China far exceeds that of its legal software. In 2011, China's legal software market was worth $\$ 2.6$ billion, but its illegal market value was nearly $\$ 9$ billion, making a piracy rate of 77 percent. ${ }^{13}$ China accounted for more than half of all pirated goods entering the United States in 2015. The value of the goods was just shy of $\$ 700$ million. $^{14}$

There is an element of pride to China's actions. The US Chamber of Commerce claims that rampant violation of IPR is not due to the lack of political will to crack down on infringers. It is a deliberate government-directed, or -motivated strategy

${ }^{8}$ W. Morrison, China-U.S. Trade Issues, Congressional Research Service Report, Washington, D.C. 2015, available online: https://www.fas.org/sgp/crs/row/RL33536.pdf (15.05.2017).

9 The Commission on the Theft of American Intellectual Property is an independent organization that documents and assesses the causes and scale of IP theft as they affect the United States. It documents and assesses the role of China in international IP theft, and proposes appropriate policy responses to protect IPR.

${ }^{10}$ The Commission on the Theft of American Intellectual Property, The Report of the Commission on the Theft of Intellectual Property, May 2013 available online: http://www.ipcommission.org/report/IP_Commission_Report_052213.pdf(15.05.2017).

11 The American Chamber of Commerce in the People's Republic of China, 2013 China Business Climate Survey Report, Beijing 2013, available online: https://www.amchamchina.org/ policy-advocacy/business-climate-survey/ 2013-business-climate-survey (15.05.2017).

${ }^{12}$ The United States International Trade Commission, China: Effects of Intellectual Property Infringement and Indigenous Innovation Policies on the U.S. Economy, USITC Publication 4226, Washington, D.C. May 2011, p. xiv, available online: https://www.usitc.gov/publications/332/ pub4226.pdf (15.05.2017).

${ }^{13}$ Business Software Alliance, Shadow Market, 2011 BSA Global Software Piracy Study, $9^{\text {th }}$ ed., Washington D.C. 2012), p. 4, available online: http://globalstudy.bsa.org/2011/ (15.05.2017).

${ }_{14}$ US Customs and Border Protection, Intellectual Property Rights, Fiscal Year 2015 Seizure Statistics, Washington, D.C. 2015, available online: https://www.cbp.gov/linkhandler/cgov/trade/priority_trade/ipr/ipr_communications/seizure/fy2012_final_stats_ctt/fy2012_final_stats.pdf(15.05.2017). 
to reduce China's reliance on foreign technology. ${ }^{15}$ For instance, the American Superconductor Corporation (AMSC) accused Sinovel Wind Group Co. Ltd., China's largest wind turbine producer, of illegal use of AMSC's intellectual property. According to the civil and criminal complaints filed, Sinovel had illegally acquired and used AMSC's wind turbine software to upgrade its 1.5 megawatt wind turbines to meet Chinese grid codes. ${ }^{16}$ The filed reports state that Sinovel had refused to pay for past shipments of components and failed to honor contracts for future shipments. In these filings, AMSC has sought to regain more than $\$ 1.2$ billion for damages and shipments due to Sinovel's contract breaches. ${ }^{17}$ There are many cases like this ${ }^{18}$ that contribute to US concerns over the vulnerability of American businesses in China. ${ }^{19}$

US firms face China's government pressure to share IPR and technology with Chinese partners. One common way that Chinese firms steal American IP is by acquiring needed technology from their US partners, and then routinely abandon those partners, claiming that the product or technology failed to meet Chinese government regulations..$^{20}$ Although the USTR reported in 2014 that China had made some improvements to its regulations and trade laws, infringement continues to be a critical problem across various types of IP in China, including trademarks, trade secrets, technical data, and copyrights. ${ }^{21}$ Sales of US IP in China remain low compared to those in other countries.

Cyber theft. Many US policymakers and analysts believe that the Chinese government is operating on a longstanding policy centered on catching up to and surpassing the West ${ }^{22}$ in economy, technological advances, and global status.

${ }^{15}$ USITC, Testimony of Jeremie Waterman, Senior Director, Greater China, U.S. Chamber of Commerce, before the U.S., International Trade Commission, Hearing on China: Intellectual Property Infringement, Indigenous Innovation Policies, and Frameworks for Measuring the Effects on the U.S. Economy, Washington, D.C. 2010, available online: https://www.usitc.gov/publications/332/pub4199.pdf (15.05.2017).

${ }^{16}$ AMSC claims Sinovel had acquired the intellectual property from a former AMSC employee who was arrested for fraudulent manipulation of data and economic espionage.

17 AMSC, Press Release, 10.04.2012, available online: http://files.shareholder.com/downloads/ AMSC/44703786040x558743/f01e0c5a-a526-4102-a818-f61f2d71ef79/AMSC_News_2012_4_10_ Commercial.pdf (15.05.2017).

${ }_{18}$ M. Nash-Hoff, What Could Be Done About China's Theft of Intellectual Property?, "IndustryWeek" 9.02.2016, available online: http://www.industryweek.com/intellectual-property/ what-could-be-done-about-chinas-theft-intellectual-property (15.05.2017).

19 Ibidem; B.T. Yeh, Protection of Trade Secrets: Overview of Current Law and Legislation, Congressional Research Service Report, Washington, D.C. 2016, available online: https://fas.org/ sgp/crs/secrecy/R43714.pdf (15.05.2017); W.M. Morrison, op. cit.

20 E. Ailworth, Data Theft Case May Test U.S. China Ties, "Boston Globe" 19.09.2011, available online: https:/www.bostonglobe.com/business/2011/09/19/data-theft-case-may-test-china-ties/esqDoiBUGU5334kudq1sbI/story.html (15/05/2017).

${ }^{21}$ W.M. Morrison, op. cit.

22 Z. Feng, New National Strategy Provides Insight Into China 's Rise, “China Brief” 3.09.2004, available online: https://jamestown.org/program/new-national-strategy-provides-insight-into-chinas-rise/ (15.05.2017). 
There are many cases that substantiate Chinese government involvement in IP violations and cyber security attacks. In 2013, Mandiant, a U.S. security company, published a report detailing cyber espionage by a Chinese company with alleged connections to the China's military. This company, APT1, targeted 141 firms and 20 industries in the past decade. Mandiant's analysis revealed that APT1 is one of China's most persistent cyber thieves. It found that the PLA's cyber unit 61398 is similar to APT1 in its mission, capabilities, and resources. It is also located in the same area from which APT1 actively appears to originate. ${ }^{23}$ The US Department of Justice in May 2014 issued a 31-count indictment against five members of the PLA for espionage and other offenses that targeted five US firms. ${ }^{24}$ In response, China denied the charges and suspended its participation in the US-China Cyber Working Group.

On September 24, 2015, during a White House visit, Chinese President Xi Jinping and US President Obama reached a "common understanding" on cyber theft. Although Xi did not publicly acknowledge that China conducted or that Beijing supported cyber espionage, Obama stated, "we have agreed that neither the US or the Chinese government will conduct or knowingly support cyber enabled theft of intellectual property, including trade secrets or other confidential business information for commercial advantage." ${ }^{25}$ The two leaders also committed to creating an entity that would meet twice a year to address cybercrime and to improve bilateral communication when cyber-related concerns arise. Some US analysts view this as a good path to create new rules covering cyber theft of commercial IP. Other analysts are quite skeptical due to the Chinese government's claims that China is the "biggest victim" 26 of such activity by the US. Despite the discussion between the two state leaders, there was no signed agreement to back up the verbal understanding between the two leaders.

Just a month after Xi's visit and the articulation of the "common understanding" on cyber theft, CrowdStrike, a security company, published a blog claiming that hackers believed to be connected to the Chinese government via Deep

${ }^{23}$ Mandiant, API1: Exposing One of China's Cyber, Espionage Units, Milpitas, CA, 2003, available online: https://www.fireeye.com/content/dam/fireeye-www/services/pdfs/mandiant-apt1-report. $\operatorname{pdf}(15.05 .2017)$.

${ }^{24}$ The five firms are Westinghouse; US subsidiaries of SolarWorld; US Steel; Allegheny Technologies Inc (ATI); United Steel, Paper, and Forestry, Rubber, Manufacturing, Energy, Allied Industrial and Service Workers International Union (USW); and Alcoa Inc; US Department of Justice, U.S. Charges Five Chinese Military Hackers for Cyber Espionage Against U.S. Corporations and a Labor Organization for Commercial Advantage, Washington, D.C. 2014, available online: https://www.justice.gov/opa/pr/us-charges-five-chinese-military-hackers-cyber-espionage-against-us-corporations-and-labor (15.05.2017).

${ }^{25}$ K. Zetter, US and China Reach Historic Agreement on Economic Espionage, "Wired" 25.09.2015, available online: https://www.wired.com/2015/09/us-china-reach-historic-agreementeconomic-espionage/ (12.10.2016).

${ }^{26}$ Ibidem. 
Panda attacked seven companies. ${ }^{27}$ "Deep Panda." CrowdStrike uses the term for Chinese military-affiliated hackers who continue to be linked to numerous covert information intrusions. ${ }^{28}$ Deep Panda has several aliases, including PinkPanther, Group 72, and KungFu Kittens. ${ }^{29}$

Skeptics of the Xi-Obama verbal agreement point to continuous violations. Director of National Intelligence James Clapper told the Senate Armed Services Committee that he doubted that efficacy of the informal agreement. Commander of the US Northern Command in charge of homeland defense, Admiral William Gortney, claimed that China would "have to show me that they're going to stop. I just don't see that happening. They can't keep their industry moving without robbing our intellectual capital...they're robbing us blind." ${ }^{30}$

Chinese government-sponsored cyber hacking appears to be escalating, despite Beijing's denials of involvement. Cyberattacks into Fortune 500 companies to steal personal data and intellectual property continue. Researchers have evidence that Chinese hackers finance future infiltrations by selling access to information stolen from computers in vulnerable US companies. In other cases, the Chinese government is uses Virtual Private Networks (VPNs) as a hacking tool. In this method, hackers use the guise of offering VPN services to those seeking to avoid Chinese government censorship of the Internet, but actually use the VPS as a platform for cyberattacks on the foreign corporations that take advantage of the service. ${ }^{31}$

World Trade Organization Issues. A second major trade issue concerns China's record on implementing its obligations under the World Trade Organization (WTO) and its failure to join the WTO's Government Procurement Agreement (GPA). ${ }^{32}$ US policymakers believed that China's 2001 accession to the WTO would encourage Beijing to reduce its interference in the Chinese economy, deepen market reforms, promote rule of law, and allow the US to use the WTO's dispute resolution mechanism to address major trade issues. The US hoped that China would become a more dependable trading partner. In the early years of China's accession, US trade officials noted positive progress in economic reforms that would increase openness and trade and transition toward a market economy. By 2006, however, progress had slowed and by 2008, US trade officials noted

${ }^{27}$ For Deep Panda report, see: Crowdstrike Global Intelligence Team, Deep Panda, Irvine, CA 2015, available online: https://assets.documentcloud.org/documents/2084641/crowdstrikedeep-panda-report.pdf (15.05.2017).

28 B. Gertz. China Continues Cyber Espionage Despite Summit Record, "Free Beacon" 19.10.2015, available online: http://freebeacon.com/national-security/china-continues-cyber-espionage-despite-summit-accord/ (15.10.2016).

29 J. Wagstaff, Hunt for Deep Panda Intensifies in Trenches of U.S.-China Cyberwar, "Reuters" 21.06.2015, available online: http://www.reuters.com/article/us-cybersecurity-usa-deeppanda-idUSKBNOP102320150621 (15.05.2017).
${ }^{30}$ Ibidem.
${ }^{31}$ Ibidem.
${ }^{32}$ W.M. Morrison, op. cit. 
that China was moving toward more restrictive trade actions. These actions included Beijing's failure to implement effective IPR enforcement, its placement of restrictions on trading and distribution rights, initiation of national standards and industrial policies that discriminated against foreign firms in favor of Chinese state firms, and its failure to make trade regulations and laws transparent. ${ }^{33} \mathrm{By}$ December 2015, the U.S. had issued seventeen dispute settlements against China, several of which have since been concluded and resolved. China has also brought nine cases against the United States. ${ }^{34}$ During President Obama's 2012 State of the Union address, he announced plans to create a new Trade Enforcement Unit responsible for "investigating unfair trade practices in countries like China." In early 2012, President Obama established the Interagency Trade Enforcement Center within the USTR's office. ${ }^{35}$

Another area of disagreement between the United States and China is Beijing's failure to accede to the WTO Government Procurement Agreement (GPA) ${ }^{36}$ as promised. China's complete accession to the GPA is a major US priority. As a non-member of the GPA, China benefits from a substantial exemption from WTO rules. ${ }^{37}$ Specifically, China may continue to employ restrictive government procurement methods that favor Chinese state firms. China's accession to GPA would mean significant economic opportunities for US firms, which would be able to participate in China's government procurement spending. In 2011, China reported its annual government procurement spending at $\$ 179$ billion, but US experts estimate spending to be approximately $\$ 200$ billion..$^{38}$ Because China is not a signatory to the GPA, it is not required to provide access to its government procurement markets..$^{39}$ Access to China government procurement market would present significant opportunities for US firms. Although China has negotiating submitted several applications between 2007and 2014, the US and other GPA members have found those applications unacceptable.

${ }^{33}$ USTR, 2013 Report to Congress on China's WTO Compliance, Washington D.C. 2013, available online: https://ustr.gov/sites/default/files/2013-Report-to-Congress-China-WTO-Compliance.pdf (15.10.2017).

${ }^{34}$ D.T. Shedd, Dispute Settlement in the World Trade Organization (WTO): An Overview, Congressional Research Service Report, Washington, D.C. 2016, available online: https://fas.org/ sgp/crs/misc/RS20088.pdf (15.05.2017).

35 W. Morrison, op. cit.

${ }^{36}$ The aim of the GPA is to open government procurement markets among its parties. Not all members of the WTO are parties to GPA, and participation in GPA is not required of WTO members.

${ }^{37}$ Ibidem.

38 Xinhua News Agency, 29.06.2012, available online: http://news.xinhuanet.com/english/ china/2012-06 (15.05.2017).

39 W. Morrison, op. cit. 


\section{MAJOR SECURITY CONCERNS IN US-CHINA RELATIONS}

This section examines US criticisms and expectations of China's behavior concerning North Korea, and territorial disputes in the East and South China Seas.

North Korea continues to be a major concern for the threat that it poses to regional security. The US is critical of China's tolerance of North Korea's leadership and its nuclear program. China is North Korea's biggest trading partner, ally, and main source of arms, energy, and food. ${ }^{40}$ China has aided in sustaining Kim Jong-un's rule, and consistently opposes all international sanctions targeting North Korea to avoid regime collapse and the inflow of refugees across its border. During President Obama's first term, his administration implemented its "strategic patience" foreign policy in which he would offer an outstretched hand to those dictatorships willing to improve relations with the United States. The Obama administration decided to apply strategic patience to encourage direct talks with the former DPRK leader, Kim Jong-il, to end a two-decade long tension over its nuclear program. Despite this approach, North Korea in Spring 2009 responded with a nuclear test and a multi-stage rocket launch. ${ }^{41}$

China's support of DPRK has opened Beijing to US criticism that Beijing is not committed to nuclear nonproliferation. In 2015, the State Department reported that China continues to supply missile parts to countries of significant concern, including North Korea. ${ }^{42}$ The Chinese Foreign Ministry responded that China has made notable contributions to nonproliferation and accused the United States of making baseless charges. ${ }^{43}$ Although Beijing had signed off on tough UN sanctions on Iran and North Korea, Chinese companies are linked to selling banned parts and weapons to both. Despite its claims to the contrary, China continues robust trade with North Korea regardless of the sanctions. In 2007, China-DPRK trade increased 21 percent in the several months after the October 2006 nuclear test in 2010.44 After North Korea's 2009 nuclear test, China's trade and investment increased to $\$ 3$ billion from $\$ 1.7$ billion in the first 11 months of $2010 .{ }^{45}$ In 2013 , the Ministry of Finance began to punish illegal financial transactions by North Korean banks and freezing assets. Following North Korea's third nuclear test in 2013, China imposed border checks and decreased bilateral trade. Despite Chinese

${ }^{40}$ S. Snyder. U.S. Policy Toward North Korea, Council on Foreign Relations, Washington D.C. 2013, available online: http://www.cfr.org/north-korea/us-policy-toward-north-korea/p29962 (14.10.2016).

${ }^{41}$ Ibidem.

${ }^{42}$ Reuters, China 'astonished' at U.S. Criticism on Nonproliferation, Business Insider 10.06.2015, available online: http://www.businessinsider.com/r-china-astonished-at-us-criticismon-nonproliferation-2015-6? IR=T (15.05.2017).

${ }^{43}$ Ibidem.

${ }^{44}$ Yonhap News Agency, China Makes Little Investment in N. Korea Since October Nuclear Test, Yonhap News Agency 2.02.2016, available online: http://english.hani.co.kr/arti/english_ edition/e_international/188324.html (06.07.2016).

${ }^{45}$ Ibidem. 
companies decreasing their exposure to North Korea due to concerns over the new sanctions, Beijing assured them that they could continue business as usual. ${ }^{46}$

Following North Korea's fourth nuclear test in January 2016, China agreed that something must be done about North Korea. Historically, China would agree that the DPRK's actions are unacceptable and then months later begin to diverge from supporting UN sanctions on North Korea. ${ }^{47}$ The United States continues to see that China applies gentle pressure. China would temporarily restrict bank transactions with Pyongyang, restrict trade and bank transactions to eventually resume normal economic trade with the DPRK in months. ${ }^{48}$ For example, if China stopped oil deliveries, North Korea would face a severe economic crisis in a year and forced to decide between a failed economy and continuing its nuclear program. ${ }^{49}$ In August to September 2006 after the July 2006 long-range missile launch, China reduced oil supplies to North Korea and exported no crude oil in September 2006. Yet, in October 2006, China resumed both exports of crude oil to North Korea and oil shipments increased 67 percent. In 2009, China suspended oil for four months but because there were no reports of oil shortages, China had pretended to stop the deliveries. Although China reported no oil exports to North Korea in 2014 or 2015, China's Public Security Bureau indicated that Beijing was supplying oil to Pyongyang. South Korea intelligence confirmed that China had secretly provided North Korea with oil. From 2006 to 2016, China similarly implemented short-term restrictions on financial transactions and bilateral trade. For instance, although current UN resolutions ban export of key DPRK commodities such as coal and iron, China insists on leniency due to "livelihood purposes." ${ }^{50}$

The United States is critical of China's defense of the DPRK in the United Nations. The United States accuses China of watering down UN resolutions concerning North Korea, denying evidence of North Korea violations, insisting on expansive loopholes, feebly enforcing UN resolutions, and blocking North Korean entities from being put on the sanctions list. ${ }^{51}$ Although the United States is aware that China seeks to avoid the collapse of North Korea and a concomitant inflow of refugees, it nevertheless expects Beijing to pressure Pyongyang to stop its

46 S. Kleine-Ahlbrandt, China's North Korea Policy: Backtracking from Sunnylands?, 38 North, U.S.-Korea Institute at SAIS, 2.07.2013, available online: http://38north.org/2013/07/ skahlbrandt070213/\#_ftn2 (15.05.2017).

47 B. Klingner, Chinese Foot-dragging on North Korea Thwarts U.S. Security Interests, Heritage Foundation, Washington D.C. 2016a, available online: http://www.heritage.org/defense/ report/chinese-foot-dragging-north-korea-thwarts-us-security-interests (15.05.2017).

${ }^{48}$ B. Klingner, Creating a Comprehensive Policy Response to North Korean Threats and Provocations, Heritage Foundation, Washington D.C. 2016b, available online: http://www.heritage.org/node/159961/print-display (15.05.2017).

49 J. Perlex, Few Expect China to Punish North Korea for Latest Nuclear Test, "New York Times" 11.09.2016, available online: https://www.nytimes.com/2016/09/12/world/asia/north-korea-china-nuclear-sanctions-thaad-america (15.05.2017).

${ }^{50}$ B. Klingner, Creating a Comprehensive Policy...

${ }^{51}$ Ibidem. 
nuclear weapons tests. The United States is navigating from a difficult position. The United States does not want the DPRK nuclear issue to jeopardize its bilateral relationship with China. Washington also knows that it cannot rely on China to put pressure on North Korea because Beijing is closer to Pyongyang than it is to Washington, and that Beijing cares more about the collapse of the DPRK and the ensuing refugee crisis than a nuclearized Korean Peninsula. ${ }^{52}$

East and South China Seas. The United States is also critical of China's increasing aggression in the East and South China seas, particularly its claim of sovereignty over the Diaoyu/Senkaku islands and the entire South China Sea, including the Spratly Islands; its maritime boundary disputes; and its proclamation of an Air Defense Identification Zone (ADIZ) in the East China Sea. ${ }^{53}$ The South China Sea provides maritime Asia a link to the West, the Middle East, and much of South and Southeast Asia. Some \$5 trillion in ship-borne trade passes through the South China Sea each year, China claims territory over most of the seas. China's territorial claims in the South China Sea violate the sovereignty of Vietnam, Malaysia, Taiwan, the Philippines, and Brunei. Despite China's routine denials that it is doing so, the United States has strongly pushed China and other countries to avoid militarizing their holdings in the South China Sea. ${ }^{54}$

China claims that it has indisputable sovereignty over the Spratly islands and nearby waters, and claims that construction on the Spratly islands and reefs is "multipurpose, mixed, and with the exception of necessary military defensive requirements, are more for serving all forms of civil needs." ${ }^{55}$ The United States has been overtly critical of Chinese claims to contested islands in the South China Sea. The United States claims that China intends to militarize the territories it controls in the South China Sea. Washington views Chinese militarization of its holding as not only destabilizing to the security of the Asia-Pacific, but as a threat to US superiority in the region.

The United States is currently concerned that China intends to declare an Area Defense Identification Zone ${ }^{56}$ (ADIZ) in the South China Sea. The United States is concerned that China will do this in response to the Permanent Court's rejection of Beijing's claims to nearly the entire South China Sea. In 2013, Beijing responded to the dispute with Japan over the sovereignty of the Diaoyu/Senkaku Islands by

52 Perlez, op. cit.

53 Oxford Public International Law, Debate Map: Disputes in the South and East China Seas, 25.07.2016, available online: http://opil.ouplaw.com/page/222/debate-map-disputes-in-the-southand-east-china-seas\#mariti meboundaryeast (15.05.2017).

54 K. Takenaka and E. Beech, Japan Warms China of Deteriorating Ties over East China Sea Dispute, "Reuters" 9.08.2016, available online: http://www.reuters.com/article/us-japan-chinaidUSKCN10K07I (15.05.2017).

55 Ibidem.

56 An Area Defense Identification Zone (ADIZ) covers most of the East China Sea where the Chinese government announced that it would impost restricts on air traffic in November 2013. 
declaring an ADIZ in the East China Sea. ${ }^{57}$ Per the rules, China demanded that any aircraft flying in the ADIZ must follow certain regulations and warned that "China's armed forces will adopt defensive emergency measures to respond to aircraft that do not cooperate in the identification." ${ }^{58}$ At the time, China's air force did not have the ability to monitor the entire airspace. China has since developed aircraft capable of ADIZ enforcement. China has developed radar coverage capable of providing China with an early warning capability unmatched by rival claimants, and capable of complicating US air and naval FONOPs. ${ }^{59}$

The United States believes that China is expanding its military capabilities in the South China Sea to accompany a future South China Sea ADIZ. In the instance that China chooses to declare a South China Sea ADIZ, it is on the right path to being able to effectively police the airspace over the Sea. ${ }^{60} \mathrm{~A}$ Chinese ADIZ in the South China Sea has several key implications for US security interests in the region. It could result in tense mid-air encounters between US and Chinese aircraft. China has already displayed a willingness to challenge US military aircraft in contested maritime areas. A Chinese ADIZ could compound operations of state and commercial aircraft in the South China Sea. Perhaps most important, China's action could change the political status quo in the South China Sea. Admiral Harry Harris, commander of the US Pacific Command, stated that fully developed Chinese military facilities in the region "creates a mechanism in which China would have de facto control over the South China Sea in any scenario short of war." ${ }^{61}$ A South China Sea ADIZ would also play a large part in inciting tensions among the other Asian countries in the region, as was the case with the East China Sea announcement. Tensions, like Japan's bold rejection of China's East China Sea ADIZ, ${ }^{62}$ could harm regional stability.

${ }^{57}$ M. Pilger, ADIZ Update: Enforcement in the East China Sea, Prospects for the South China Sea, and Implications for the United States, "U.S.-China Economic and Security Review Commission" 2.03.2016, available online: http://www.defense-aerospace.com/articles-view/ release/3/171805/30-months-on $\% 3 \mathrm{~A}$-a-look-at-china $\% \mathrm{E} 2 \% 80 \% 99$ s-adiz-in-east-china-sea.html (15.05.2017).

${ }^{58}$ J. Osawa, China's ADIZ Over the East China Sea: A “Great Wall in the Sky"?, Brookings, Washington D.C. 2013, available online: https://www.brookings.edu/opinions/chinas-adiz-overthe-east-china-sea-a-great-wall-in-the-sky/\#_ftn3 (15.05.2017)

${ }_{59}$ M. Yeo, Analysis: Can China Enforce a South China Sea Air-Defense Identification Zone? "USNI News" 18.07.2016, available online: https://news.usni.org/2016/07/18/analysis-can-chinaenforce-south-china-sea-air-defense-identification-zone (15.05.2017).

${ }^{60}$ Ibidem.

${ }^{61}$ M. Pilger, op. cit.

${ }^{62}$ Z. Feng, China's First ADIZ Decision: One Year Later, CSIS:Asia Maritime Transparency Initiative, 25.11.2014, available online: https://amti.csis.org/chinas-first-adiz-decision-one-yearlater/ (15.05.2017). 


\section{US REBALANCE POLICY}

After a decade of military engagement in the Iraq and Afghanistan, the Obama Administration in 2011 announced a strategic "pivot," reorienting US foreign policy from the Middle East to Asia. This shift, later renamed "rebalance," is largely in response to the increased economic importance of the Asia-Pacific. It is also partly in response to the perception that China has adopted a more muscular foreign policy, backed by a rapidly modernizing military, and that this new assertiveness threatens the peace and security of the region. Rebalance policy seeks to maintain US power in the Asia-Pacific by strengthening diplomatic, economic, and security ties with the region.

Diplomacy. US diplomacy under rebalance focuses on strengthening alliances with US regional allies and friends, expanding relations with Singapore and India, and a higher level of engagement with multilateral institutions. ${ }^{63}$ Since 2012, the United States has carried out numerous presidential and cabinet-level visits to the region. To deepen relations with Thailand, the pivot focuses on encouraging the military government to reinstate civil liberties and democratic law.

A critical aspect of the rebalance is its focus on emerging partners, who are crucial for continued US leadership in the region. Among these emerging partners are Vietnam and Indonesia. The US-Vietnam relationship improvements include human rights, military cooperation, and peacekeeping. ${ }^{64}$ In 2015, President Obama expanded cooperation with Indonesia through education, environment, and health objectives. ${ }^{65}$ The United States has also strengthened relations in the region by hosting the first US-ASEAN Summit in the United States, sending the first ambassador to ASEAN, and hosting APEC in 2011. ${ }^{66}$ These institutions are crucial to advance security, economic and political related engagement that are essential to continue to assure our partners and allies that the U.S. is a critical and permanent partner.

The United States is also assertively courting India. Initially reluctant to choose sides between the United States and China, India is increasingly concerned that China is attempting to create a China-centric geopolitical order in Asia. India's Prime Minister Narendra Modi's tilt toward the United States became apparent during President Obama's visit to New Delhi in January $2015 .{ }^{67}$ During the visit,

${ }^{63}$ R. Sutter, M. Brown, T. Adamson, M. Michizuki, and D. Ollapally, Balancing Acts: US Rebalance and Asia Pacific Security, Washington D.C. 2013, p. 2.

${ }^{64}$ Ibidem

65 The White House, FACTSHEET: Advancing the Rebalance to Asia and the Pacific, 16.11.2015, available online: https://www.whitehouse.gov/the-press-office/2015/11/16/fact-sheetadvancing-rebalance-asia-and-pacific (15.05.2017).

${ }^{66}$ Ibidem.

${ }^{67}$ S. Parashar and S. Dasgupta, US, India's Asia-Pacific vision makes the Chinese dragon uneasy, "The Times of India" 28.01.2015, available online: http://www.lexisnexis.com.ezproxy. umw.edu/hottopics/lnacademic/? (06.04. 2015). 
the two countries finalized bilateral agreements on economic development and security cooperation and on defense and regional security.

While a solid network of reginal allies and friends would contain China's expansion in the Asia-Pacific, the Obama administration has also sought greater engagement with China, thereby hoping to diffuse tension in the region. In 2013, Obama and Xi Jinping met informally in California and discussed their concerns over cyber-espionage and protection of intellectual property rights, North Korea, desire for peaceful resolution of island disputes, China's economic challenges and reforms, and China's desire to protect its sovereignty. Discussion of these issues continued in more detail that summer by US and Chinese cabinet-level officials at the Strategic and Economic Dialogue, held in Washington.

Economic statecraft. Rebalance has deepened economic relations in the region by promoting mutually beneficial investment and trade for the United States and its regional allies and friends. The core of US economic engagement in the region is the Trans-Pacific Partnership (TPP), a free trade agreement among twelve Pacific nations but excludes China. The objective of TPP is to maintain a strong economic environment, in which every member commits to standing against corruption and bribery, adhering to international labor standards, including creation of independent trade unions, and agrees to enforcement of environmental safeguards. ${ }^{68}$ The Obama Administration argues that the TPP will boost economic growth and jobs through expanded trade and investment with countries currently accounting for nearly 40 percent of total US trade; deepen US trade and investment integration; and eliminate more than 18,000 taxes on American exports and leveling the playing field for American workers. The Obama Administration also argues that the TPP has strategic value. Because the TPP excludes China, the agreement would essentially write the rules of the game, strengthening US allies and partners and reaffirming US economic leadership in the region. ${ }^{69}$ Unfortunately, the fate of TPP is uncertain. Although all twelve countries have signed the agreement, the US Congress has not yet approved it. The two US presidential candidates, Hillary Clinton and Donald Trump, disavowed it. The Obama Administration believes TPP failure would cost the United States in geopolitical terms. The administration views TPP as a counter to growing Chinese economic and political influence. A failure by the United States to pass the TPP would give China space to determine regional rules of commerce and diplomacy through its own trade and investment initiatives. China has proposed a Free-Trade Area of the Asia Pacific (FTAAP) to counter TPP. Failure to follow through on TPP would potentially reduce US presence and power in the region.

68 Ibidem.

69 I. F. Fergusson, M.A. McMinimy, B.R. Williams, The Trans-Pacific Partnership (TPP): In Brief, Congressional Research Service Report, Washington, D.C. 2016, available online: https:// fas.org/sgp/crs/row/R44278.pdf (15.05.2017). 
Security. Lastly, rebalance seeks to protect the existing security order in the Asia-Pacific. By increasing US partners' maritime security capacity, allies can better counter China's South China Sea and other claims that encroach on other countries' territories. To maintain the existing order, the United States plans to position 60 percent of the US Navy in the region by the end of the decade. ${ }^{70} \mathrm{Re}$ blance solidified existing US alliances with Japan, South Korea, and Australia. The United States and Japan updated Guidelines for Japan-US Defense Cooperation, which govern cooperation during peacetime. The 2015 Guidelines call for the two countries to cooperate in maintaining freedom of navigation in the region by sharing intelligence, surveillance and reconnaissance (ISR), and by training and maritime exercises. The updated US-Japan mutual defense pact allows Japan to come to US aid even if Japan were not attacked. Perturbed by the North Korean threat to its national security, South Korea is discussing with the United States additional deployment of "strategic assets," such the nuclear-powered aircraft carrier USS Ronald Reagan - currently based in Japan - B-2 bombers, nuclear-powered submarines and F-22 stealth fighter jets, and possibly Terminal High Altitude Area Defense (THAAD). The United States signed a Force Posture Agreement with Australia, and in 2016, began rotational deployment of US Marines to Darwin. It finalized an Enhanced Defense Cooperation Agreement (EFCA) with the Philippines, ${ }^{71}$ which allows the United States to use Subic Bay base for the first time in almost 20 years.

Rebalance also enhances security agreements with southeast Asia, and forges new political and security relationships with Vietnam, Indonesia, and India. In late 2015, the United States and Singapore signed an enhanced defense cooperation agreement (DCA). That expands cooperation in the military, policy, strategic and technology spheres, along with cooperation against non-traditional security threats such as terrorism and piracy. Since late 2015, Singapore has allowed the US Navy to operate surveillance planes from its airfields, enabling the United States to gather intelligence on China's military activity in the South China Sea. ${ }^{72}$ Since 2008, the United States and Vietnam have held annual bilateral defense and security talks, and in 2010 the United States declared that FON in the South China Sea to be in its national interest. In 2016, the US removed the ban on the sale of weapons to Hanoi. Under rebalance, the US has expanded defense and security cooperation with Malaysia in efforts to combat counterterrorism, human trafficking, and maritime offenses. The United States also seeks to bring the Indian Ocean into its Asia-Pacific policy by deepening political and security ties with Delhi. In 2015, Washington and Delhi released a joint strategic vision, agreeing to

${ }^{70}$ A. Blinken, U.S.-China Relations: Strategic Challenges and Opportunities, U.S. Department of State, Washington D.C., 27.04. 2016, available online: http://www.state.gov/s/d/2016d/ 256657.htm (15.05.2017).

${ }^{71}$ Ibidem.

72 The United States also operates P-8 plans from Japan and the Philippines. 
ensure freedom of navigation and overflight, especially in the South China Sea. ${ }^{73}$ In 2016, the United States and India agreed to allow the two countries' militaries to use each other's bases for replenishment and repair. The United States and India are in the midst of talks to coproduce advanced military hardware in India.

Rebalance and Congagement. Some American scholars disagree that rebalance is about containing China. American China scholar Robert Sutter argues that rebalance is not a strategy to contain China, largely because the Obama administration recognizes that a new Cold War does not benefit the United States. Officially, the Obama Administration welcomes China's peaceful rise, and claims that it is in America's interest to see China succeed. ${ }^{74}$ These positive sentiments reflect Obama's 'congagement' policy in which the United States encourages US-China engagement, but uses a strong military presence to signal US resolve.

\section{CONCLUSION}

US President Obama continued a policy of congagement characteristic of his immediate predecessors. Although the United States continues to engage China with robust trade, there are areas of tension, such as IP theft and cyber theft, and China's failure to meet its obligations under WTO. Another area of engagement was the Obama administration's efforts to draw China more deeply into US concerns over the North Korean nuclear threat. Overall, the Obama administration leaves office as frustrated as the Bush administration by Beijing's lack of cooperation in reigning in Pyongyang. A second significant area of US-China tension is China's behavior in the East and South China Seas. Washington views China's assertiveness in the Asia-Pacific as not merely a question of China asserting historic claims to sovereignty, but as a challenge to US supremacy in the region. As a result, the United States is using a containment strategy to preserve the status quo. US reengagement policy is not merely a thinly veiled containment policy that seeks physical barriers against China's expansion, however. Rather, it seeks to make China play by the rules of the game by building alliances with US allies and friends in the region, enhance trade agreements and a heightened military presence in the Asia-Pacific.

The 2016 election of Donald Trump to the US presidency raises the question of whether his administration will continue US congagement policy. On the campaign trail and shortly after his election victory, Trump accused China of being currency manipulator and an unfair trade partner. ${ }^{75}$ Although deeming a nation

${ }^{73}$ White House, U.S.-India Joint Strategic Vision for the Asia-Pacific and Indian Ocean Region, 25.01.2015, available online: https://www.whitehouse.gov/the-press-office/2015/01/25/ us-india-joint-strategic-vision-asia-pacific-and-indian-ocean-region (15.05.2017).

${ }^{74}$ R. Sutter, M. Brown, T. Adamson, M. Michizuki, and D. Ollapally, op. cit.

75 New York Daily News, Full transcript of Donald Trump's 2016 presidential announcement, "New York Daily News" 16.06.2015, available online: http://www.nydailynews.com/ 
a currency manipulator does not automatically trigger trade tariffs on the offending party, it creates a tit-for-tat atmosphere in bilateral relations. Regarding cyber theft, President-elect Trump announced in a video on his plans for the first 100 days in office a plan to beef up US cyber security. He also pledged to withdraw from TPP.

It also remains to be seen if President Trump will continue US rebalance policy. ${ }^{76}$ While on the campaign trail, Trump stated that he wanted to withdraw American troops from Asia so South Korea and Japan would defend themselves and suggested they should create their own nuclear weapons. ${ }^{77}$ Not only would Trump's proposal increase the possibility of war between Japan and China, but it would weaken validity of the Nuclear Non-Proliferation Treaty. ${ }^{78}$ Trump's view of the US role in Asia exposes Taiwan to military action by China. Faced with this existential threat and lack of US resolve, Taiwan may choose to develop nuclear weapons to deter China. ${ }^{79}$

Shortly after Trump's victory, Japanese Prime Minister Shinzo Abe, travelled to Washington to discuss the future of US-Japan relations. ${ }^{80}$ Trump has also diverged from his prior hardline rhetoric on South Korea. In a conversation between Korean President Park Geun-hye after his election, Trump assured her that the United States was committed to working with Seoul to protect against the instability in North Korea. ${ }^{81}$

Tytul: Polityka prezydenta B. Obamy wobec Chin - analiza krytyczna.

news/politics/transcript-donald-trump-2016-presidential-announcement-article-1.2260117 (15.05.2017); S. Vaishampayan, Donald Trump charges China with Yuan manipulation-Again, "Wall Street Journal” 26.09.2016, available online: https://www.wsj.com/articles/donald-trumpcharges-china-with-yuan-manipulationagain-1474943701 (15.05.2017); South China Morning Post, Trump in 'Gettysburg Address' pledges to label China a currency manipulator in first 100 days as president, U.S.-China Relations: Strategic Challenges and Opportunities, "South China Morning Post" 23.10.2016), available online: http:/www.scmp.com/news/world/united-states-canada/ article/2039327/trump-tries-channel-abraham-lincoln-he-lays-out-plan; Trump-Pence campaign website, https://www.donaldjtrump.com/policies/trade (27.11.2016).

${ }^{76}$ US reengagement began in practice, but not in name, at the end of the George W. Bush presidency.

77 M. O'Hanlon, If a President Trump Turns His Back on Taiwan, "Wall Street Journal" 4.07.2016, available online: http://www.wsj.com/articles/if-a-president-trump-turns-his-back-ontaiwan-1467650733 (15.05.2017).

${ }^{78}$ Ibidem.

79 Ibidem.

${ }^{80}$ R. Yoshida, Abe Quickly Sets Up Meeting With Trump in New York, "The Japan Times" 10.11.2016, available online: http://www.japantimes.co.jp/news/2016/11/10/national/politics-diplomacy/abe-trump-look-meet-next-week-new-york/\#.WCZWW4STAhZ (15.05.2017).

${ }^{81}$ E. Hu, Japan and South Korea Rattled By Trump's Talk of Closing U.S. Bases, "NPR" 10.11.2016, available online: http://www.npr.org/sections/parallels/2016/11/10/501531166/japanand-south-korea-rattled-by-trumps-talk-of-closing-u-s-bases (15.05.2017). 
Streszczenie: Polityka Stanów Zjednoczonych prowadzona wobec Chin w ciągu ostatniego ćwierćwiecza, pomimo różnic ideologicznych występujących pomiędzy kolejnymi prezydentami USA, odznaczała się wyjątkową spójnością. Prezydenci Stanów Zjednoczonych, których polityka zagraniczna była zbieżna z liberalną szkołą stosunków międzynarodowych, z reguły starali się oponentów angażować, aby w ten sposób doprowadzić do ich pozytywnej przemiany. Realiści z kolei próbują ograniczyć wpływ przeciwnika i powstrzymują jego potęgę. Od wczesnych lat 1990-tych prezydenci USA stosowali zarówno powstrzymywanie, jak i zaangażowanie. Najbardziej liberalny spośród prezydentów USA na przestrzeni ostatnich 25 lat, Barack Obama początkowo prowadził wobec Chin politykę angażowania. Dostrzegając jednak, iż Chiny coraz wyraźniej stanowią wyzwanie dla dominacji USA w regionie Azji i Pacyfiku, stopniowo wdrożył elementy polityki powstrzymywania. Prezentowany artykule zawiera analizę polityki administracji B. Obamy wobec Chin, w szczególności rozważa się w nim, czy polityka ta była spójna. We wnioskach stwierdzono, że zrównoważenie polityki administracji Obamy wobec Azji i Pacyfiku jest zgodne z amerykańską polityką Chin z czasów poprzednich administracji.

Słowa klucze: Polityka USA wobec Chin, Barack Obama, region Azji i Pacyfiku

\section{BIBLIOGRAPHY}

1. AILWORTH E., 2011: Data Theft Case May Test U.S. China Ties, "Boston Globe" 19.09, available online: https://www.bostonglobe.com/business/2011/09/19/data-theft-case-may-testchina-ties/esqDoiBUGU5334kudq1sbI/story.html (15/05/2017).

2. THE AMERICAN CHAMBER OF COMMERCE IN THE PEOPLE'S REPUBLIC OF CHINA, 2013: 2013 China Business Climate Survey Report, Beijing, available online https://www. amchamchina.org/policy-advocacy/business-climate-survey/2013-business-climate-survey (15.05.2017).

3. AMSC, 2012: Press Release, 10.04, available online: http://files.shareholder.com/downloads/AMSC/447037860 40x558743/f01e0c5a-a526-4102-a818-f61f2d71ef79/AMSC_ News_2012_4_10_Commercial.pdf (15.05.2017).

4. BLINKEN A., 2016: U.S.-China Relations: Strategic Challenges and Opportunities, U.S. Department of State, Washington D.C., available online: http://www.state.gov/s/d/2016d/256657. htm (15.05.2017).

5. BUSINESS SOFTWARE ALLIANCE, 2012: Shadow Market, 2011 BSA Global Software Piracy Study, $9^{\text {th }} e d$., Washington D.C., available online: http://globalstudy.bsa.org/2011/ (15.05.2017).

6. The Commission on the Theft of American Intellectual Property, 2013: The Report of the Commission on the Theft of Intellectual Property, available online http://www.ipcommission.org/ report/IP_Commission_Report_052213.pdf (15.05.2017).

7. CROWDSTRIKE GLOBAL INTELLIGENCE TEAM, 2015: Deep Panda, Irvine, CA, available online: https://assets.documentcloud.org/documents/2084641/crowdstrike-deep-panda-report.pdf (15.05.2017).

8. FENG Z., 2004: New National Strategy Provides Insight Into China's Rise, "China Brief” 3.09, available online: https://jamestown.org/program/new-national-strategy-provides-insight-intochinas-rise/ (15.05.2017).

9. FENG Z., 2014: China's First ADIZ Decision: One Year Later, CSIS:Asia Maritime Transparency Initiative, 25.11, available online: https://amti.csis.org/chinas-first-adiz-decision-one-yearlater/ (15.05.2017). 
10. FERGUSSON I.F., MCMINIMY M.A., WILLIAMS B.R., 2016: The Trans-Pacific Partnership (TPP): In Brief, Congressional Research Service Report, Washington, D.C., available online: https://fas.org/sgp/crs/row/R44278.pdf (15.05.2017).

11. FRIEDBERG A.L., 2011: A Contest for Supremacy: China, America and the Struggle for Mastery in Asia, New York 2011.

12. GERTZ B., 2015: China Continues Cyber Espionage Despite Summit Record, "Free Beacon" 19.10, available online: http://freebeacon.com/national-security/china-continues-cyber-espionage-despite-summit-accord/ (15.10.2016).

13. HU E., 2016: Japan and South Korea Rattled By Trump's Talk of Closing U.S. Bases, "NPR" 10.11, available online: http://www.npr.org/sections/parallels/2016/11/10/501531166/japanand-south-korea-rattled-by-trumps-talk-of-closing-u-s-bases (15.05.2017).

14. KLEINE-AHLBRANDT S., 2013: China 's North Korea Policy: Backtracking from Sunnylands?, 38 North, U.S.-Korea Institute at SAIS, 2.07, available online: http://38north.org/2013/07/skahlbrandt070213/\#_ftn2 (15.05.2017).

15. KLINGNER B., 2016a: Chinese Foot-dragging on North Korea Thwarts U.S. Security Interests, Heritage Foundation, Washington D.C., available online: http:/www.heritage.org/defense/ report/chinese-foot-dragging-north-korea-thwarts-us-security-interests (15.05.2017).

16. KLINGNER B., 2016b: Creating a Comprehensive Policy Response to North Korean Threats and Provocations, Heritage Foundation, Washington D.C., available online: http://www.heritage.org/node/159961/print-display (15.05.2017).

17. MANDIANT, 2003: API1: Exposing One of China's Cyber Espionage Units, Milpitas, CA, available online, https://www.fireeye.com/content/dam/fireeye-www/services/pdfs/mandiantapt1-report.pdf (15.05.2017).

18. MORRISON W., 2015: China-U.S. Trade Issues, Congressional Research Service Report, Washington, D.C., available online: https://www.fas.org/sgp/crs/row/RL33536.pdf (15.05.2017).

19. NASH-HOFF M., 2016: What Could Be Done About China's Theft of Intellectual Property?, "IndustryWeek" 9.02, available online: http://www.industryweek.com/intellectual-property/ what-could-be-done-about-chinas-theft-intellectual-property (15.05.2017).

20. NEW YORK DAILY NEWS, 2015: Full transcript of Donald Trump's 2016 presidential announcement, "New York Daily News" 16.06, available online: http://www.nydailynews.com/ news/politics/transcript-donald-trump-2016-presidential-announcement-article-1.2260117 (15.05.2017).

21. O'HANLON M., If a President Trump Turns His Back on Taiwan, "Wall Street Journal" 4.07, available online: http://www.wsj.com/articles/if-a-president-trump-turns-his-back-ontaiwan-1467650733 (15.05.2017).

22. OFFICE OF THE UNITED STATES TRADE REPRESENTATIVE, 2016: The People's Republic of China, available online: https://ustr.gov/countries-regions/china-mongolia-taiwan/ peoples-republic-china (31.10.2016).

23. OSAWA J., 2013: China's ADIZ Over the East China Sea: A "Great Wall in the Sky"?, Brookings, Washington D.C. 2013, available online: https://www.brookings.edu/opinions/chinas-adizover-the-east-china-sea-a-great-wall-in-the-sky/\#_ftn3 (15.05.2017)

24. OXFORD PUBLIC INTERNATIONAL LAW, 2016: Debate Map: Disputes in the South and East China Seas, 25.07, available online: http://opil.ouplaw.com/page/222/debate-map-disputesin-the-south-and-east-china-seas\#mariti meboundaryeast (15.05.2017).

25. PARASHAR S., DASGUPTA S., 2015: US, India's Asia-Pacific vision makes the Chinese dragon uneasy, "The Times of India" 28.01, available online: http://www.lexisnexis.com.ezproxy. umw.edu/hottopics/lnacademic/? (06.04. 2015). 
26. PERLEX J., 2016: Few Expect China to Punish North Korea for Latest Nuclear Test, "New York Times" 11.09, available online: https://www.nytimes.com/2016/09/12/world/asia/north-korea-china-nuclear-sanctions-thaad-america (15.05.2017).

27. PILGER M., 2016: ADIZ Update: Enforcement in the East China Sea, Prospects for the South China Sea, and Implications for the United States, "U.S.-China Economic and Security Review Commission" 2.03, available online: http://www.defense-aerospace.com/articles-view/ release/3/171805/30-months-on $\% 3 \mathrm{~A}$-a-look-at-china $\%$ E2\%80\%99s-adiz-in-east-china-sea. html (15.05.2017).

28. REUTERS, 2015: China 'astonished' at U.S. Criticism on Nonproliferation, Business Insider 10.06, available online: http://www.businessinsider.com/r-china-astonished-at-us-criticism-onnonproliferation-2015-6? IR= $\mathrm{T}(15.05 .2017)$.

29. SHEDD D.T., 2016: Dispute Settlement in the World Trade Organization (WTO): An Overview, Congressional Research Service Report, Washington, D.C., available online: https://fas.org/sgp/ $\mathrm{crs} / \mathrm{misc} / \mathrm{RS} 20088 . p d f(15.05 .2017)$.

30. SNYDER S., 2013: U.S. Policy Toward North Korea, Council on Foreign Relations, Washington D.C., available online http://www.cfr.org/north-korea/us-policy-toward-north-korea/p29962 (14.10.2016).

31. SOUTH CHINA MORNING POST, 2016: Trump in 'Gettysburg Address' pledges to label China a currency manipulator in first 100 days as president, U.S.-China Relations: Strategic Challenges and Opportunities, "South China Morning Post" 23.10, available online: http:// www.scmp.com/news/world/united-states-canada/article/2039327/trump-tries-channel-abraham-lincoln-he-lays-out-plan;

32. SUTTER R., BROWN M., ADAMSON T., MICHIZUKI M., OLLAPALLY D., 2013: Balancing Acts: US Rebalance and Asia Pacific Security, Washington D.C.

33. TAKENAKA K., Beech E., 2016: Japan Warms China of Deteriorating Ties over East China Sea Dispute, "Reuters" 9.08, available online: http://www.reuters.com/article/us-japan-chinaidUSKCN10K07I (15.05.2017).

34. TRUMP-PENCE CAMPAIGN WEBSITE, 2016, https://www.donaldjtrump.com/policies/trade (27.11.2016).

35. US CUSTOMS AND BORDER PROTECTION, 2015: Intellectual Property Rights, Fiscal Year 2015 Seizure Statistics, Washington, D.C., available online: https:/www.cbp.gov/linkhandler/ cgov/trade/priority_trade/ipr/ipr_communications/seizure/fy2012_final_stats_ctt/fy2012_final_stats.pdf (15.05.2017).

36. THE UNITED STATES INTERNATIONAL TRADE COMMISSION, 2011: China: Effects of Intellectual Property Infringement and Indigenous Innovation Policies on the U.S. Economy, USITC Publication 4226, Washington, D.C., available online: https://www.usitc.gov/publications/332/pub4226.pdf (15.05.2017).

37. US DEPARTMENT OF DEFENSE, 2001: Quadrennial Defense Review Report US Department of Defense 2001, Washington, D.C., available online, http://archive.defense.gov/pubs/qdr2001. pdf (15.05.2017).

38. US DEPARTMENT OF DEFENSE,1997: Report of the Quadrennial Defense Review, Washington, D.C., available on-line: http://history.defense.gov/Portals/70/Documents/quadrennial/ QDR1997.pdf?ver=2014-06-25-110930-527 (15.05.2017).

39. US DEPARTMENT OF JUSTICE, 2014: U.S. Charges Five Chinese Military Hackers for Cyber Espionage Against U.S. Corporations and a Labor Organization for Commercial Advantage, Washington, D.C., available online: https:/www.justice.gov/opa/pr/us-charges-five-chinesemilitary-hackers-cyber-espionage-against-us-corporations-and-labor (15.05.2017). 
40. US INTERNATIONAL TRADE COMMISSION, 2016, USITC Interactive Tariff and Trade DataWeb, available on-line: https://dataweb.usitc.gov (15.05.2017).

41. USITC, 2010: Testimony of Jeremie Waterman, Senior Director, Greater China, U.S. Chamber of Commerce, before the U.S., International Trade Commission, Hearing on China: Intellectual Property Infringement, Indigenous Innovation Policies, and Frameworks for Measuring the Effects on the U.S. Economy, Washington, D.C., available online: https://www.usitc.gov/ publications/332/pub4199.pdf(15.05.2017).

42. USTR, 2013: 2013 Report to Congress on China's WTO Compliance, Washington D.C., available online: https://ustr.gov/sites/default/files/2013-Report-to-Congress-China-WTO-Compliance.pdf (15.10.2017).

43. VAISHAMPAYAN S., 2016: Donald Trump charges China with Yuan manipulation-Again, "Wall Street Journal” 26.09, available online: https://www.wsj.com/articles/donald-trumpcharges-china-with-yuan-manipulationagain-1474943701 (15.05.2017).

44. WAGSTAFF J., 2015: Hunt for Deep Panda Intensifies in Trenches of U.S.-China Cyberwar, "Reuters" 21.06, available online: http://www.reuters.com/article/us-cybersecurity-usa-deeppanda-idUSKBNOP102320150621 (15.05.2017).

45. WANG D., 2013: The United States and China: A History from the Eighteenth Century to the Present, Lanham, MD.

46. WHITE HOUSE, 2002: The National Security Strategy of the United States of America, Washington, D.C. 2002, available online: http://www.state.gov/documents/organization/63562.pdf (15.05.2017).

47. WHITE HOUSE, 2015: FACTSHEET: Advancing the Rebalance to Asia and the Pacific, 16.11, available online: https://www.whitehouse.gov/the-press-office/2015/11/16/fact-sheet-advancing-rebalance-asia-and-pacific (15.05.2017).

48. WHITE HOUSE, 2015: U.S.-India Joint Strategic Vision for the Asia-Pacific and Indian Ocean Region, 25.01, available online: https://www.whitehouse.gov/the-press-office/2015/01/25/usindia-joint-strategic-vision-asia-pacific-and-indian-ocean-region (15.05.2017).

49. XINHUA NEWS AGENCY, 2012: 29.06.2012, available online: http://news.xinhuanet.com/ english/china/2012-06 (15.05.2017).

50. YEH T., 2016: Protection of Trade Secrets: Overview of Current Law and Legislation, Congressional Research Service Report, Washington, D.C., available online: https://fas.org/sgp/crs/ secrecy/R43714.pdf (15.05.2017).

51. YEO M., 2016: Analysis: Can China Enforce a South China Sea Air-Defense Identification Zone? "USNI News" 18.07, available online: https://news.usni.org/2016/07/18/analysis-canchina-enforce-south-china-sea-air-defense-identification-zone (15.05.2017).

52. YONHAP NEWS AGENCY, 2016: China Makes Little Investment in N. Korea Since October Nuclear Test, Yonhap News Agency 2.02., available online: http://english.hani.co.kr/arti/english_edition/e_international/188324.html (06.07.2016).

53. YOSHIDA R., 2016: Abe Quickly Sets Up Meeting With Trump in New York, "The Japan Times" 10.11, available online: http://www.japantimes.co.jp/news/2016/11/10/national/politicsdiplomacy/abe-trump-look-meet-next-week-new-york/\#.WCZWW4STAhZ (15.05.2017).

54. ZETTER K., 2015: US and China Reach Historic Agreement on Economic Espionage, "Wired" 25.09., available online: https://www.wired.com/2015/09/us-china-reach-historic-agreementeconomic-espionage/ (12.10.2016). 